\title{
STAND-ALONE PHOTOVOLTAIC SYSTEM WITH THREE ENERGY PROCESSING STAGES
}

\author{
Levy F. Costa, René P. Torrico-Bascopé \\ Energy Processing and Control Group - GPEC, Electrical Engineering Department, Federal University of Ceará \\ levyfcosta@gmail.com, rene@dee.ufc.br
}

\begin{abstract}
A circuit configuration of low power standalone photovoltaic (PV) system adequate to supply residences located in isolated areas is proposed in this paper. The system consists of the association of three converters to process the energy generated by the PV panels. The proposed system is composed by a charge controller, a modified SEPIC (Single-Ended Primary Inductance Converter) topology and a full-bridge inverter with wide range of output voltage. Theoretical analysis of each stage and experimental results of the complete system is presented for a $500 \mathrm{~W}$ prototype.
\end{abstract}

Keywords - High Voltage Gain DC-DC Converter, Inverter, MPPT, Photovoltaic System.

\section{INTRODUCTION}

The increase of global energy demand associated to oil crisis and worldwide concern about the environmental pollution has motivated large investments in research related to renewable energy. Among the crescent renewable sources, the PV technology received significant amount of investments, reducing its price considerably. With the PV panels evolution, there has been a relevant development in the field of power electronic converters applied to PV systems. Several topologies and PV systems configurations have been proposed in the literature, as well as many maximum power point tracking (MPPT) algorithms.

Currently, PV systems are widely used in various areas and regions around the world. However, the cost of generated kilowatt hour is not competitive in the energy market yet, due its high cost compared to other energy source, such as hydropower [1]. On the other hand, for applications in isolated areas, where the expansion of power grid is costly and not predicted, the PV system becomes the most attractive option.

In Brazil, there is a social program maintained by the federal government named "Light for Everyone" ("Luz Para Todos" in portuguese), whose objective is to support two million people without electricity in their homes, which are located in isolated areas [2]. In order to provide electric energy supply, the most common solution lies in the use of a stand-alone PV system. The aforementioned program has then demanded the use of systems with two-day autonomy and ac output voltage with the same characteristics of the local power grid [2]. Some topologies that aim to achieve such specifications are described as follows.

Figure 1 shows a stand-alone PV system based on the boost converter, a Full-Bridge inverter and a bidirectional battery charger, as reported in [3-4]. This structure presents

Artigo submetido em 22/09/2011. Revisado em 09/11/2011. Aceito para publicação em 21/11/2011 por recomendação do editor João Onofre P. Pinto. high voltage DC link, reducing its size and weight. The batteries are not directly connected to the DC link, protecting them in an eventual fault occurrence. As a drawback, the system presents two conversion stages to charge the batteries; and two conversion stages to supply the load, fed by the batteries, decreasing the overall efficiency.

The decentralized PV system shown in Figure 2 was proposed in [5-6]. This configuration presents as advantage higher energy conversion efficiency in case of shading or malfunctioning of one or more panels. On the other hand, this type of system uses higher number of converters, increasing cost, weight and size of the topology. Other drawback lies in the use of two conversion stages to charge the batteries, also decreasing the system overall efficiency.

Figure 3 shows a boost converter and a low frequency multilevel inverter as proposed in [7-8]. The main advantage of this topology is the high efficiency due the low frequency operation of multilevel inverter. On the other hand, the significant number of active switches and the low frequency transformer increases the cost, size and weight of the system, which is suitable for medium power application.

Figure 4 shows a PV system based on Boost converter with the three-state switching cell for battery charge and a Full-Bridge low frequency isolation inverter reported in [910]. This structure used a commercial UPS inverter to reduce the global price; however this kind of inverters presents low efficiency, compromising the overall efficiency. Due the low voltage battery bank, the use of a low frequency transformer is necessary, increase the weight and size.

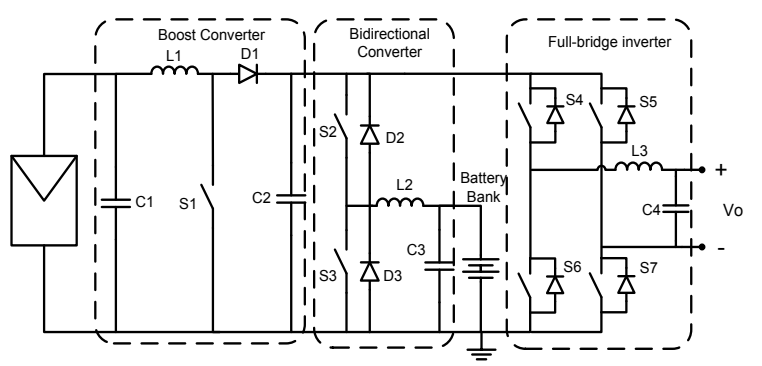

Fig. 1. PV system configuration presented in [3-4].

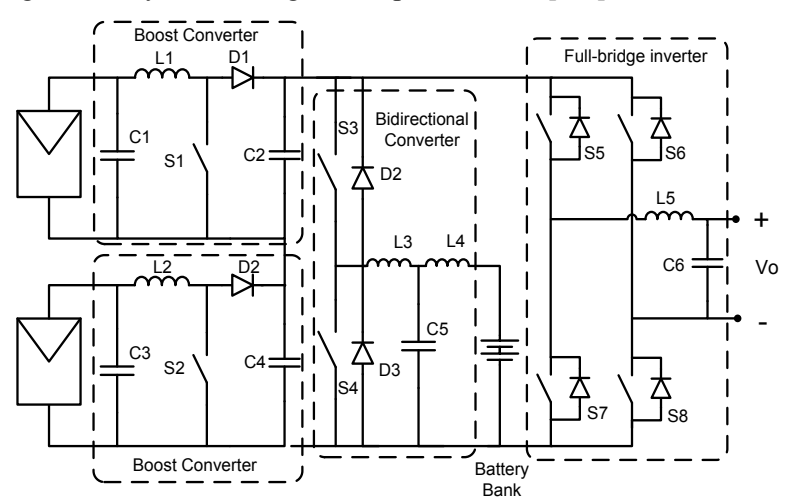

Fig. 2. Decentralized PV system [5-6]. 


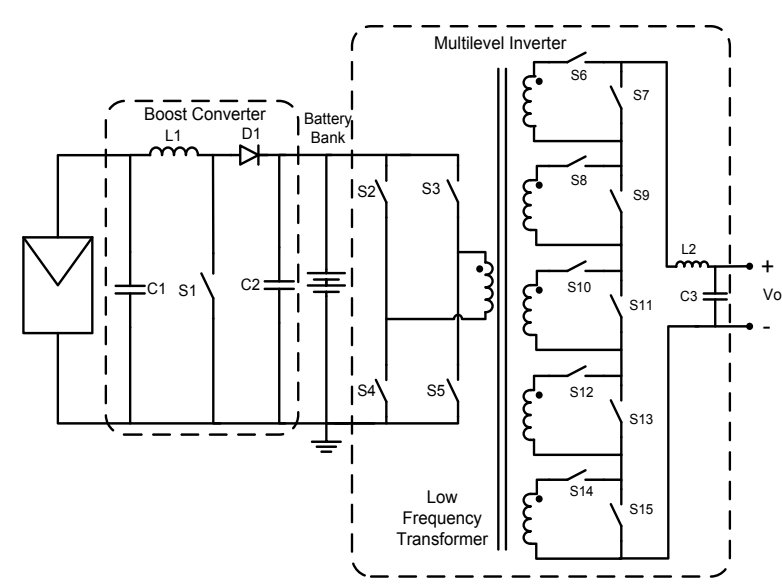

Fig. 3. PV system configuration proposed in [7-8].

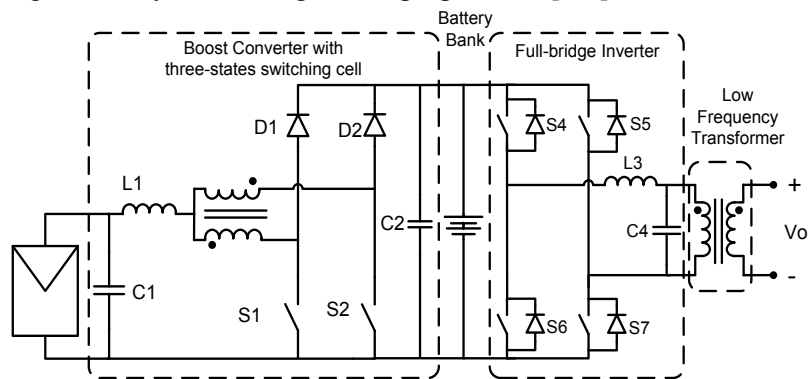

Fig. 4. PV system configuration presented in [9-10].

Within this context, this paper presents a stand-alone PV system based on classical series configuration adapted to the requirements of Brazilian social program "Light for Everyone". The structure, which is composed by a charge controller, a step-up DC-DC converter and an inverter, uses a single conversion stage to charge the batteries and two conversion stages to supply the load (less processing stages when compared with systems proposed in Figure 1 and Figure 2). Furthermore, the structure has the battery bank connected directly to the main bus, therefore the charge current through the batteries is not controlled. To increase the batteries lifetime, the maximum output current of the charge controller must be lower than the maximum allowed charge current of the batteries. On the other hand, any fault in the inverter can affect the batteries and the load. To solve this problem, it is proposed a novel topology of step-up DC-DC converter to feed the inverter and protect the batteries and load in an eventual fault occurrence. Moreover a simple supervision system can be used, due the simplicity of structure.

In order to extend the application to the whole Brazilian territory, the ac output voltage of the proposed system must have frequency of $60 \mathrm{~Hz}$ and rms value varying among 110, $115,120,127,220$ and $230 \mathrm{~V}$, which are values typically adopted in the Brazil. The description of the proposed system, theoretical analysis regarding each stage, as well as experimental results of the complete system are shown and discussed in this paper.

\section{DESCRIPTION OF PROPOSED SYSTEM}

Figure 5 shows the complete circuit of the proposed standalone PV system. The first converter is based on boost topology and responsible for maximum power point tracking (MPPT) and charging the batteries. The second stage is based on modified topology of SEPIC converter employing the three-state switching cell [11]. This topology presents as advantage low voltage across the controlled switches, which allows the use of switches with reduced on-resistance, thus decreasing conduction losses. Other significant issue lies in the fact that there is not a direct path for dc current between the input and output of the converter due the capacitor C3. Then the converter is able to protect the battery bank and the load during fault condition. Although the step-up converter topology presents two inductors, they are magnetically coupled, reducing the number of magnetics. The third stage, responsible for the dc-ac conversion, is based on classical full-bridge inverter. The supervisory system is based on an 8bit high-performance microcontroller PIC18F452.

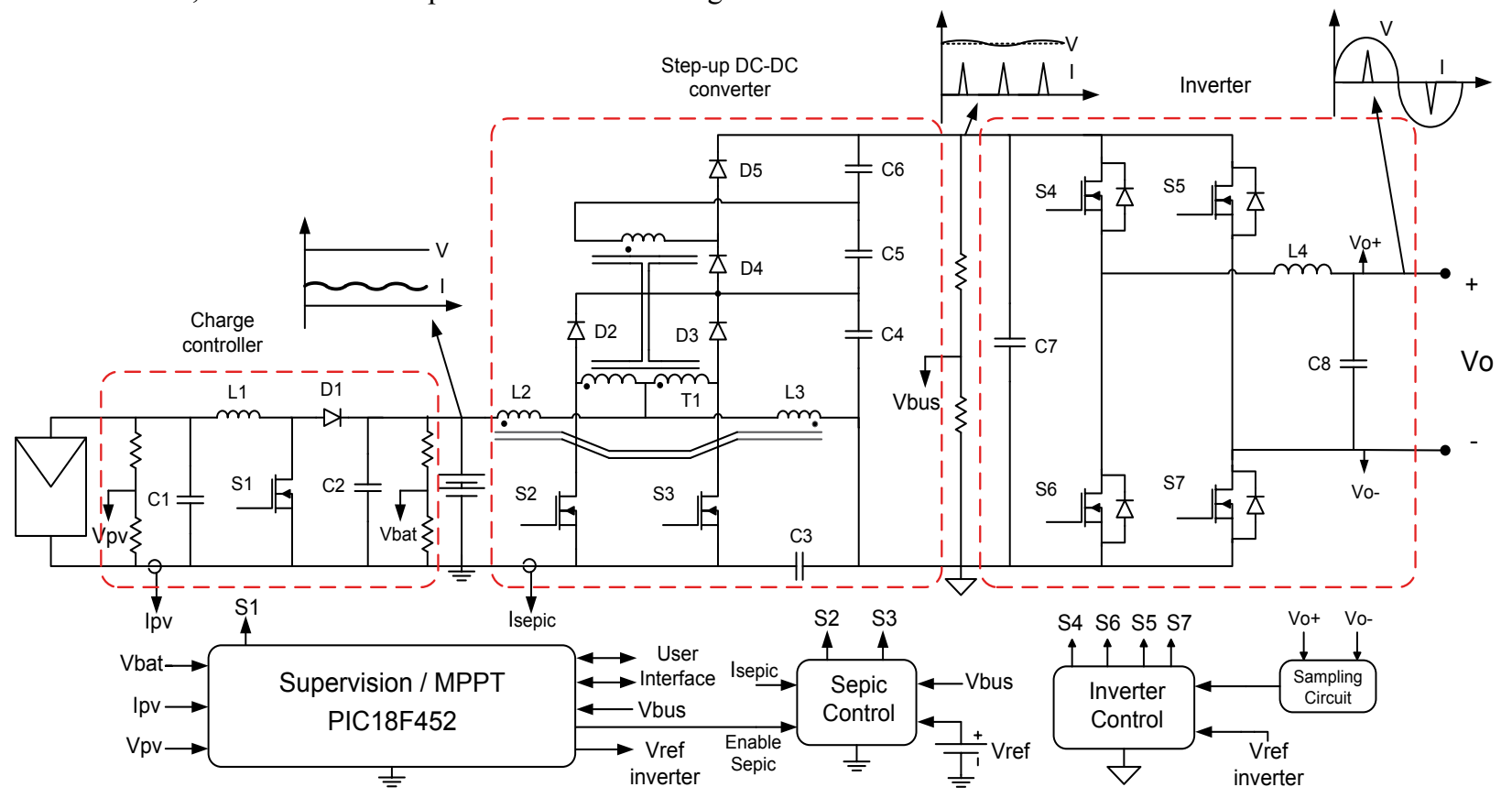

Fig. 5. Proposed PV system. 


\section{FIRST STAGE - CHARGE CONTROLLER}

The charge controller based on boost converter is responsible for tracking the maximum power operation point of PV panel and charge the batteries. The strategy was implemented in a microcontroller, including the MPPT algorithm and the output voltage control.

MPPT is based on the classic and effective Perturb\&Observe ( $\mathrm{P} \& \mathrm{O})$ algorithm. An optimal $\mathrm{P} \& \mathrm{O}$ algorithm design was developed according to [12-13]. When the batteries are fully charged, MPPT is off and the output voltage control is on. This control action is based on previously calculated constant duty-cycle in order to maintain the batteries voltage equal to the fluctuation value and avoid discharge or overcharge of batteries.

In order to obtain soft-commutation and improve the efficiency of the boost converter, a nondissipative snubber was employed, as proposed by [14-15], providing zero current switching (ZCS) at turn on.

The boost converter and the control scheme, as well as the control flowchart are shown in Figures 6 and 7 respectively.

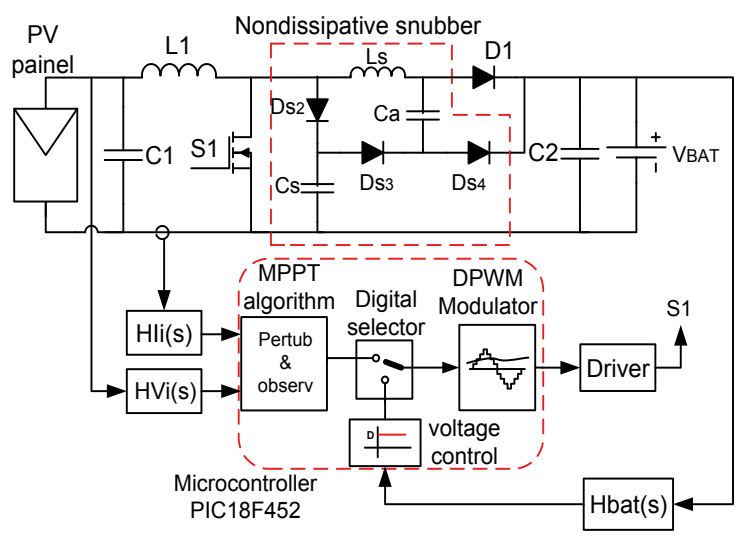

Fig. 6. Charge controller topology and scheme control.

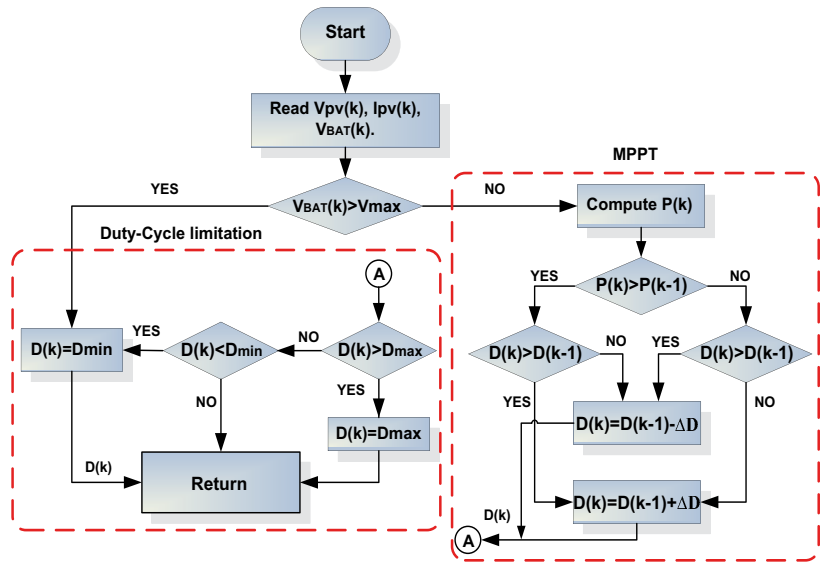

Fig. 7. Flowchart of used MPPT algorithm.

\section{SECOND STAGE - STEP-UP DC-DC CONVERTER}

The second stage is based on a novel topology of SEPIC converter using the three-state switching cell [11]. It is responsible for increasing the batteries voltage level from $48 \mathrm{Vcc}$ to $400 \mathrm{Vcc}$. Additionally, this stage provides active filtering to block the pulsating current of the nonlinear load (i.e. the inverter stage) from the battery bank. Due to the presence of capacitor $\mathrm{C} 3$, there is no direct path for the dc current between the input and output of the converter, and in fault condition the battery voltage is not applied to the system output. Thus, the converter protects the battery bank and the load against faults regarding the inverter. It is important to note that just part of rated output power of the converter is processed by the transformer, which is an advantage when compared with isolated topologies.

The converter operates with PWM modulation and duty cycle higher than 0.5 . The control strategy is based on average current mode control [16]. Figure 8 shows the converters circuit and the control scheme.

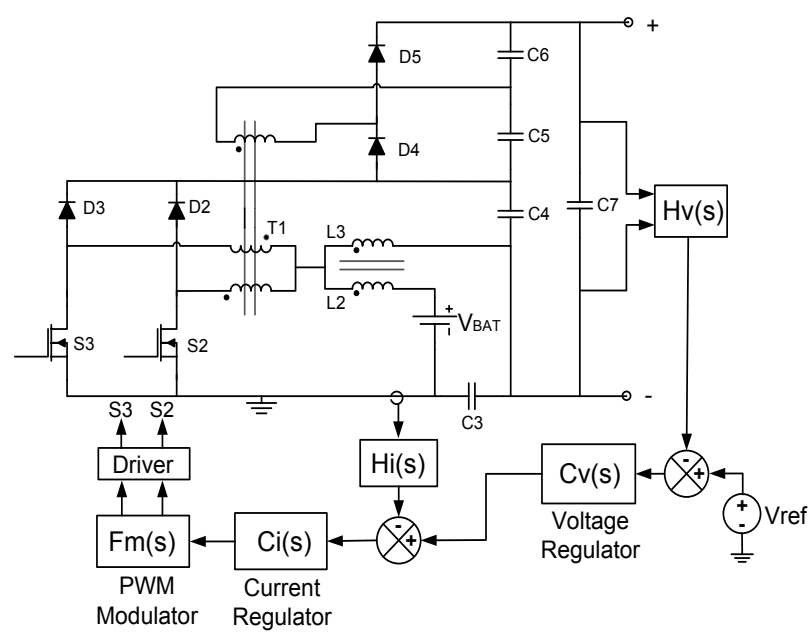

Fig. 8. Step-up DC-DC converter topology and control scheme.

\section{A. Principle of Operation}

In order to explain the principle of operation of this converter, the steady-state operation in CCM is analyzed. Considering the semiconductors and magnetic elements ideal, it is possible to observe four operating intervals that are shown in Figure 9 and described as follows. The theoretical waveforms are shown in Figure 10, where $T s$ represents the switching period for the active switches.

First Interval $\left(\boldsymbol{t}_{0}, \boldsymbol{t}_{1}\right)$ : Switches S2 and S3 are turned-on. Energy is stored in inductor L2, which is supplied by the input voltage source, and also in inductor L3, which is then supplied by capacitor C3. In this stage, there is no energy transfer to the load. The relevant differential equations during this stage are (1) and (2). This stage finishes when S2 is turned-off.

$$
\begin{aligned}
& L_{2} \cdot \frac{d i_{L 2}}{d t}-V_{B A T}=0 \\
& L_{3} \cdot \frac{d i_{L 3}}{d t}-V_{C 3}=0
\end{aligned}
$$

Second Interval $\left(t_{1}, t_{2}\right)$ : In this stage switch S3 remains turned on. Diodes D2 and D4 are directly biased. The energy stored in the inductors in the first stage, as well as the energy from the voltage source, is transferred to the filter capacitors C4, C5, C6, and the load. The differential equations representing this stage are (3) and (4).

$$
\begin{aligned}
& L_{2} \cdot \frac{d i_{L 2}}{d t}+\frac{V_{B A T}}{2 \cdot(1-D)}-V_{B A T}=0 \\
& L_{3} \cdot \frac{d i_{L 3}}{d t}+\frac{V_{B A T}}{2 \cdot(1-D)}-V_{C 3}=0
\end{aligned}
$$




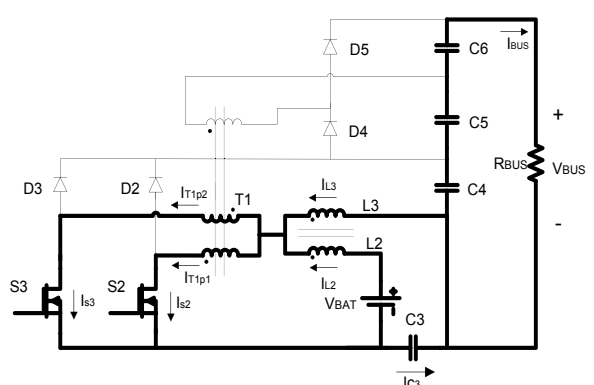

(a) First Stage

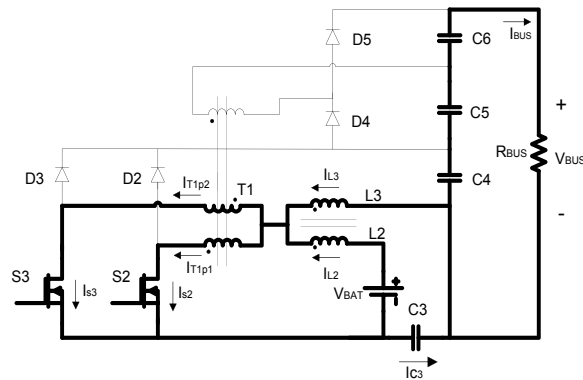

(c) Third Stage

Fig. 9. Principle of operation of the step-up DC-DC converter.

Third Stage $\left(t_{2}, t_{3}\right)$ : This stage is similar to the first one. Switches S2 and S3 are on and energy is stored in inductors L2 and L3.

Fourth Stage $\left(\boldsymbol{t}_{3}, \boldsymbol{t}_{4}\right)$ : During this stage, switch S2 remains turned-on and S3 is off. Diodes D3 and D5 are directly biased. The energy stored in the inductors in the third stage, as well as the energy from the voltage source, is transferred to filter capacitors C4, C5, C6, and the load.

\section{B. Output Characteristic}

The static gain of the converter is given by (5). The corresponding curves for a given transformer turns ratio are shown in Figure 11.

$$
G_{V}=\frac{V_{B U S}}{V_{B A T}}=\frac{D+n}{1-D}
$$

Where $n$ is the transformer turns ratio and $\mathrm{D}$ is the duty cycle.

\section{Semiconductors Design}

The maximum normalized voltage across switches $\mathrm{S} 2$ and S3, without considering overshoots is given by (6), where $\mathrm{V}_{\mathrm{BAT}}$ is the battery bank voltage.

$$
V S_{2}=V S_{3}=\frac{V_{B A T}}{1-D}
$$

The maximum reverse voltage across the diodes D2, D3, D4, and D5 are given by (7) and (8), respectively.

$$
\begin{gathered}
V D_{2}=V D_{3}=\frac{V_{B A T}}{1-D} \\
V D_{4}=V D_{5}=\frac{n \cdot V_{B A T}}{1-D}
\end{gathered}
$$

\section{Design of Inductors, Transformer and Capacitors}

Inductors L2 and L3 are magnetically coupled and have the same inductance, as given by (9).

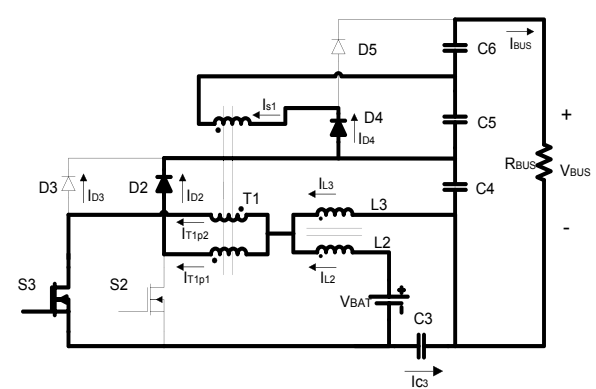

(b) Second Stage

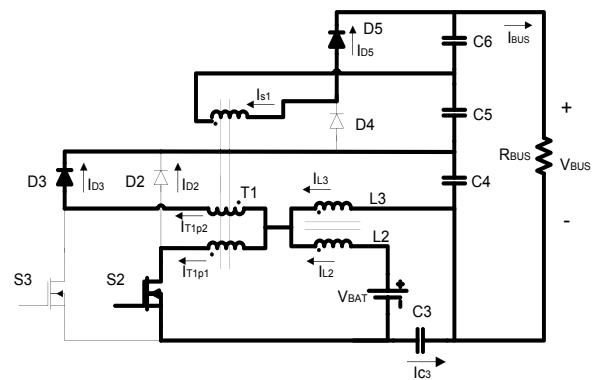

(d) Fourth Stage

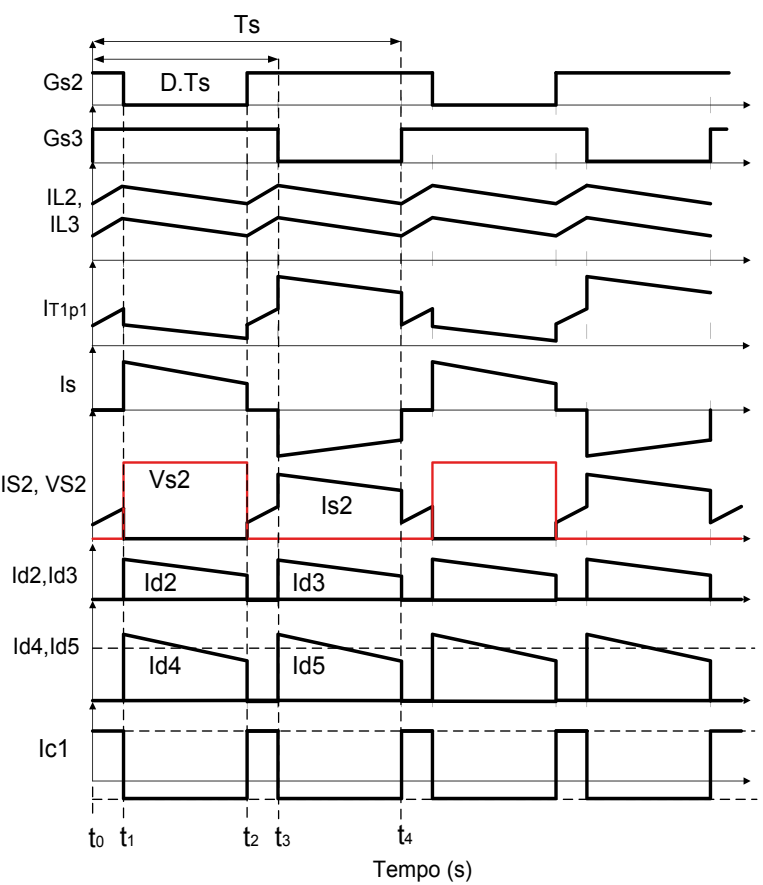

Fig. 10. Main theoretical waveforms for the step-up dc-dc converter.

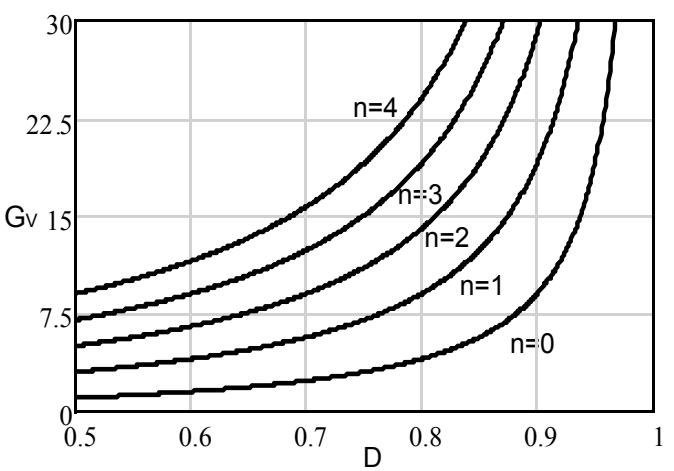

Fig. 11. Static gain of the converter. 


$$
L_{2}=L_{3}=\frac{V_{B U S}}{16 \cdot f_{s} \cdot(n+0.75) \cdot \Delta I_{L 2}}
$$

Where $\Delta \mathrm{I}_{\mathrm{L} 2}$ is the current ripple through the inductor $\mathrm{L} 2$.

The high frequency transformer must be designed according to the amount of processed power given by (10), where $\mathrm{P}_{\mathrm{p}}$ is the power processed by the transformer and $\mathrm{P}_{\text {osepic }}$ is the output power of the converter.

$$
P_{P}=\frac{(2 \cdot n+1)}{(n+1)} \cdot \frac{P_{\text {oSepic }}}{2}
$$

The capacitors can be determined by using expressions (11) and (12), where, $\Delta \mathrm{V}_{\mathrm{C} 3,4}$ is the voltage ripple across capacitors $\mathrm{C} 3$ and $\mathrm{C} 4$, and $\Delta \mathrm{V}_{\mathrm{C} 5,6}$ is the voltage ripple across the capacitors $\mathrm{C} 5$ and $\mathrm{C} 6$.

$$
\begin{gathered}
C_{3}=C_{4} \geq \frac{P_{\text {oSepic }}}{16 \cdot f_{s} \cdot \Delta V_{C 3,4} \cdot V_{B A T} \cdot(n+0.75)} \\
C_{5}=C_{6} \geq \frac{P_{\text {oSepic }}}{2 \cdot f_{s} \cdot \Delta V_{C 5,6} \cdot V_{B A T} \cdot(n+0.5)}
\end{gathered}
$$

\section{THIRD STAGE - INVERTER}

The third energy processing stage is based on the classical full-bridge inverter using sinusoidal PWM unipolar modulation. It is responsible for generating a high quality sinusoidal voltage, with low total harmonic distortion (THD) and the same characteristics of local power grid where the system is supposed to be installed. Then, the inverter must provide sinusoidal waveform voltage with frequency of $60 \mathrm{~Hz}$ and rms value of 110,115, 120, 127, 220 and $230 \mathrm{Vac}$, as it was mentioned before.

The control strategy is based on the voltage mode control implemented with proportional-integral-derivative (PID) controller, and several references of signal voltages taxed into of PIC18F452 microcontroller. According to the required output voltage for the inverter, the reference voltage signal of the feedback loop is selected using two push buttons, as proposed in [17]. The output voltage selection algorithm is presented in [17], as well as the design procedure for both power and control circuits. Figure 12 shows the power circuit and control block diagram of the adopted full-bridge inverter.

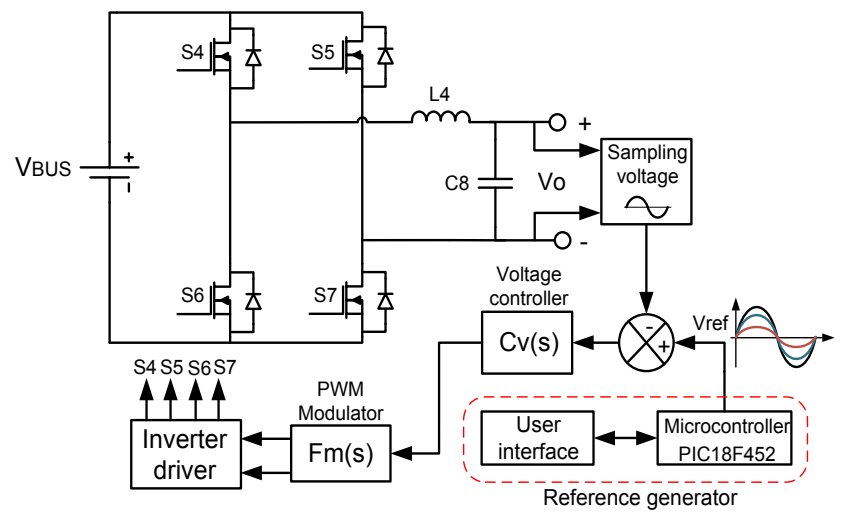

Fig. 12. Full-Bridge inverter topology and block diagram of the control.

\section{EXPERIMENTAL RESULTS}

The proposed PV system design specifications are shown in Tables I to IV. The experimental results consist of relevant voltage and current waveforms and also curves that demonstrate the performance of PV system.

TABLE I

PV System Specification

\begin{tabular}{ll}
\hline Output power & $500 \mathrm{~W}$ \\
\hline Output voltage & $110,115,120,127$, \\
& 220 and $230 \mathrm{Vac}$ \\
\hline Output voltage frequency & $60 \mathrm{~Hz}$ \\
\hline Output power factor & 0.7 \\
\hline Number of batteries & 4 x Freedom $(12 \mathrm{~V}, 150 \mathrm{Ah})$ \\
\hline Battery bank voltage & Series connection. \\
\hline Number of PV panel & $48 \mathrm{Vdc}$ \\
\hline Configuration of PV panels & $\begin{array}{l}6 / \text { Siemens SM55 } \\
(55 \mathrm{~W}, 17 \mathrm{Vdc})\end{array}$ \\
\hline DC bus & 3 in parallel. \\
\hline Autonomy & $400 \mathrm{Vdc}$ \\
\hline
\end{tabular}

TABLE II

Charge Controller Parameters First stage - Boost converter

\begin{tabular}{|c|c|}
\hline \multicolumn{2}{|c|}{ Second stage - SEPIC converter } \\
\hline Diodes D2, D3 & 30СТH03 \\
\hline Diodes D4, D5 & 30ЕTH06 \\
\hline Inductors L2, L3 & $\begin{array}{l}\mathrm{L} 2=160 \mu \mathrm{H} / \mathrm{L} 3=160 \mu \mathrm{H} \\
\mathrm{NEE}-42 / 21 / 20(\text { Thornton Ipec) } \\
\mathrm{NL} 2=27 \text { turns }(22 \times 26 \mathrm{AWG}) \\
\mathrm{NL} 3=29 \text { turns }(3 \times 26 \mathrm{AWG}) \\
\delta=1 \mathrm{~mm} \text { (gap) }\end{array}$ \\
\hline Capacitors C3, C4, C5, C6 & $2.2 \mu \mathrm{F} / 400 \mathrm{~V} /$ Polypropylene \\
\hline Capacitor C7 & $470 \mu \mathrm{F} / 450 \mathrm{~V} /$ Eletrolytic \\
\hline Switches S2, S3 & IRFP90N20D \\
\hline Transformator T1 & $\begin{array}{l}\text { NEE-42/21/20(Thornton Ipec) } \\
\text { Np1=Np2=14turns }(14 \times 26 A W G) \\
\text { Ns1=32 turns }(4 \times 25 \text { AWG })\end{array}$ \\
\hline
\end{tabular}

\begin{tabular}{ll}
\hline & First stage - Boost converter \\
\hline & $\mathrm{L} 1=230 \mathrm{uH}$ \\
& $\mathrm{NEE}-42 / 21 / 15$ \\
& $\mathrm{~N}=39$ turns $(16 \mathrm{x} 26 \mathrm{AWG})$ \\
& $\mathrm{lg}=0,105 \mathrm{~cm}$ \\
\hline Inductor L1 & $\mathrm{IRF} 8010$ \\
\hline Switch S1 & MBR20100CT \\
\hline Diode D1 & Eletrolytic $-1000 \mathrm{uF} / 100 \mathrm{~V}$ \\
\hline Capacitor C1 & Eletrolytic $-4 \times 220 \mathrm{uF} / 100 \mathrm{~V}$ \\
\hline Capacitor C2 & MUR460 \\
\hline Diodes Ds2, Ds3 e Ds4 & Polypropylene - 82nF/100V \\
\hline Capacitor Cs & Polypropylene - 560nF/100V \\
\hline Capacitor Ca & $\mathrm{Ls}=2,27 \mathrm{uH}$ \\
\hline & $\mathrm{NEE}-20 / 10 / 5$ \\
Inductor Ls & $\mathrm{N}=2$ turns $(16 \times 26 \mathrm{AWG})$ \\
& $\mathrm{lg}=0.08 \mathrm{~m}$ \\
\hline
\end{tabular}

TABLE III

Step-up DC-DC Converter Parameters 
TABLE IV

Inverter Parameters

\begin{tabular}{ll}
\hline \multicolumn{2}{c}{ Third stage - Full-Bridge Inverter } \\
\hline & $\mathrm{L} 4=613 \mu \mathrm{H}$ \\
Filter Inductor L4 & NEE-42/21/20 \\
& NL4 $=60$ turns (22x26AWG) \\
& $\delta=1 \mathrm{~mm}$ (gap) \\
\hline Filter Capacitor C8 & $10 \mathrm{uF} / 250 \mathrm{Vac}$ \\
\hline Switches S1, S2, S3, S4 & $\mathrm{IRFP} 460$ \\
\hline
\end{tabular}

As the system presents several possible output voltages, the experimental results are presented just for the extreme cases, i.e. output voltage of $110 \mathrm{Vac}$ and $230 \mathrm{Vac}$. Figure 13 shows the picture of implemented prototype.

\section{A. MPPT Algorithm Verification}

In order to test the efficiency of the MPPT algorithm described in section III, a sweep mode was implemented in the microcontroller. This mode consists in continuously changing the converter duty cycle, i.e. starting with null duty cycle and increasing it until unity, making the converter operate around all possible points. Then, when the duty cycle reaches its maximum value, the sweep mode is disabled and MPPT mode is enabled. Figure 14 shows the PV panel voltage, current and power. From this figure, the four operation stages can be seen. In the first one, the converter is off, and the circuit is open; in the second one, sweep mode is started and the PV power increases until a maximum point, and then it is decreased to zero; in the third stage, the microcontroller sets the duty-cycle to zero to properly configure its periphericals and the MPPT mode is active; in the fourth stage, the maximum power point is achieved and the system operates around this point. Figure 15 shows the detail of the PV panel extracted power, where it can be seen that MPPT algorithm has achieved the maximum power.

\section{B. Charge Controller and Step-Up Converters Waveforms}

In order to demonstrate the efficiency of the passive snubber, the switch commutation is analyzed in detail. Figures 16 and 17 show the turn on and turn off of switch S1, respectively, where soft commutation during the turn-on is observed.

To verify the performance of the step-up dc-dc converter, the same aforementioned waveforms are presented. Figure 18 shows the gating signals of switches $\mathrm{S} 2$ and $\mathrm{S} 3$, and also voltage and current waveforms for primary winding of transformer T1. The same gating signals of switches S2 and S3, and also voltage and current waveforms for switch S2 are also depicted in Figure 19. Good performance of the converter is observed, without overvoltage across the switches with symmetrical waveforms.

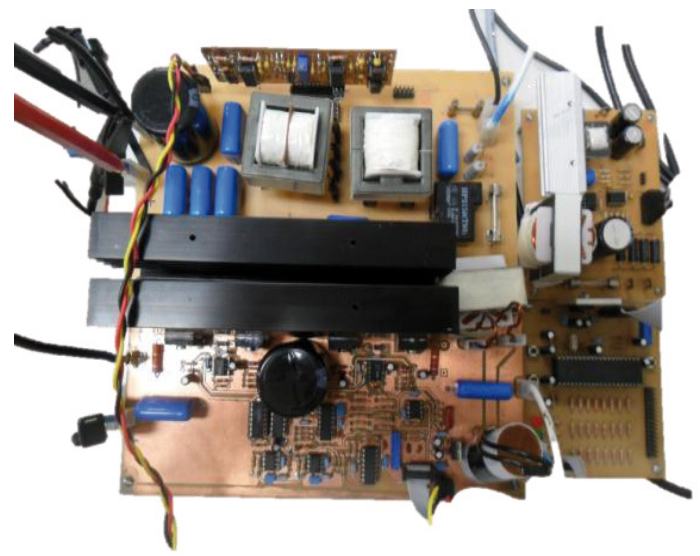

Fig. 13. Implemented prototype.

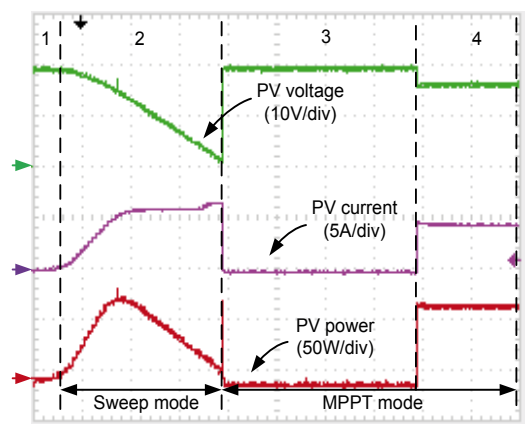

Fig. 14. PV voltage, current and power (10V/div.; 5A/div.; 50W/div.; 500ms/div.).

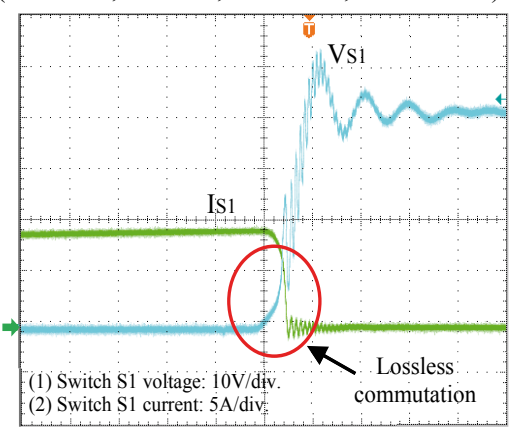

Fig. 17. Detail of switch S1 turn off for the boost converter. (10V/div.; 5A/div.; 400ns/div.).

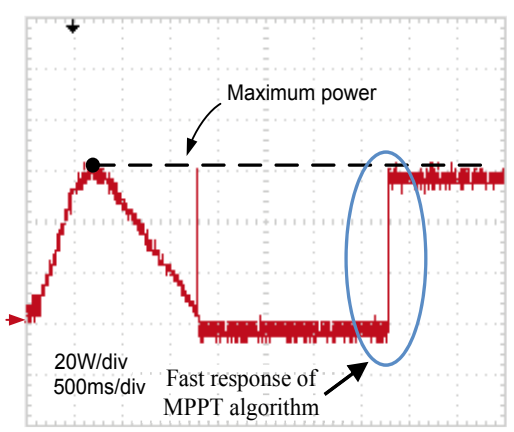

Fig. 15. Details of PV panels power (500ms/div.).

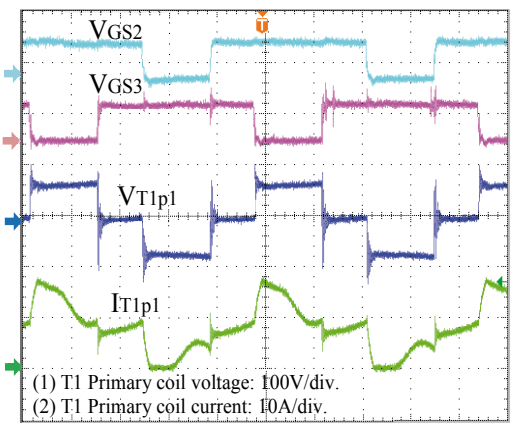

Fig. 18. Gate signals, current and voltage of the transformer T1 primary coil. (10V/div.;

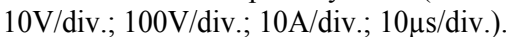

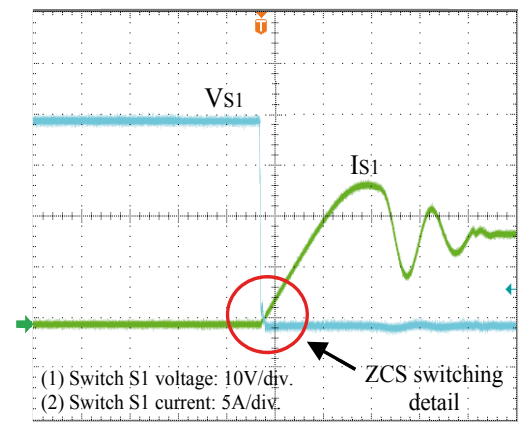

Fig. 16. Details of turn-on Boost switch S1. (10V/div.; 5A/div.; 400ns/div.).

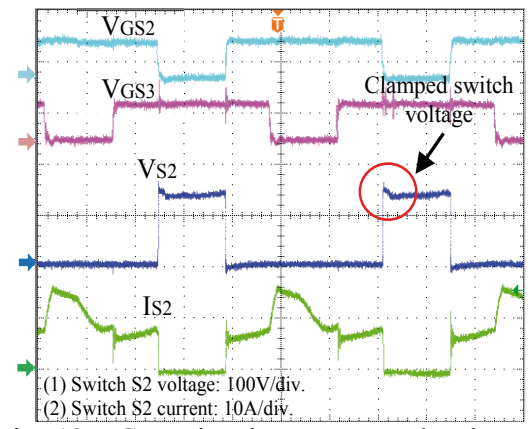

Fig. 19. Gate signals, current and voltage of the switch S2. (10V/div.; 10V/div.; 100V/div.; 10A/div.; 10us/div.). 


\section{Stead-State PV System Waveforms}

Figures 20 and 21 show the dc bus voltage, output voltage and output current when the system operates with output voltage of $110 \mathrm{~V}$ supplying linear and nonlinear load, respectively.

The corresponding waveforms for the operation with $230 \mathrm{~V}$ are shown in Figures 23 and 24. High quality sinusoidal output voltage is achieved and the dc bus voltage remains constant, regardless of the load type connected to the system. The regulated low ripple dc voltage is due to the good performance of the step-up dc-dc converter. It is observed that the system current is unbalanced due the low $\mathrm{dc}$ level in output voltage.

Figure 22 shows the battery bank current. By using the average current mode control, a continuous dc current with low ripple is drawn from the battery bank, blocking the pulsed current required by the inverter operation, thus enhancing the reliability and useful life of batteries.

\section{Transients Waveforms}

Figures 25 and 26 show the system response to a load step, from null to full load, when the system operates with output voltage of $110 \mathrm{~V}$ and $230 \mathrm{~V}$, respectively. From these figures, it is observed a high performance of the inverter controller and the step-up DC-DC converter controller, showing good output voltage dynamic response for both converters.

Figure 27 shows the output voltage variation from $220 \mathrm{~V}$ to $127 \mathrm{~V}$, where a stable DC bus and fast response of the system are verified. However, this transient may not be applied to the system in practical situation. Although the system can operate over a wide range of output voltage, it is supposed to be configured for a fixed output voltage, according to the local power grid specifications.

\section{E. Efficiency and THD}

The efficiency curves of the boost converter (first stage) with snubber and without snubber are shown in Figure 28.

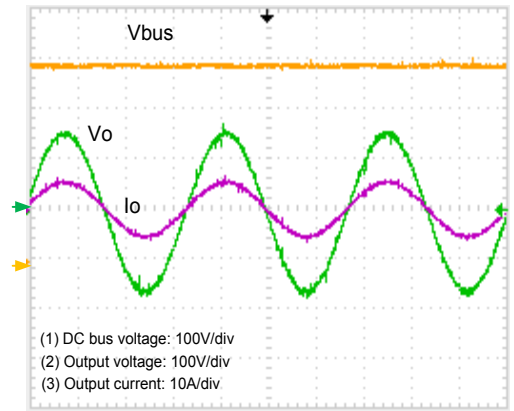

Fig. 20. DC bus, output voltage and current of the system for linear load $-\mathrm{Vo}=110 \mathrm{~V}$. (100V/div.; 100V/div.; 10A/div.; 5ms/div.).

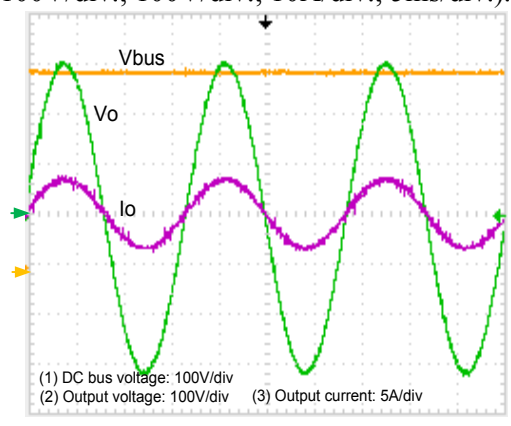

Fig. 23. DC bus, output voltage and current of the system for linear load $-\mathrm{Vo}=230 \mathrm{~V}$. (100V/div.; 100V/div.; 5A/div.; 5ms/div.).

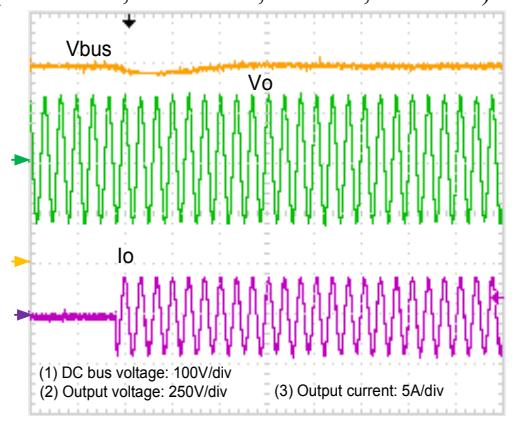

Fig. 26. DC bus, output voltage and current of the system for $\mathrm{Vo}=230 \mathrm{~V}$. $(100 \mathrm{~V} / \mathrm{div}$.; 250V/div.; 5A/div.; 50ms/div.).

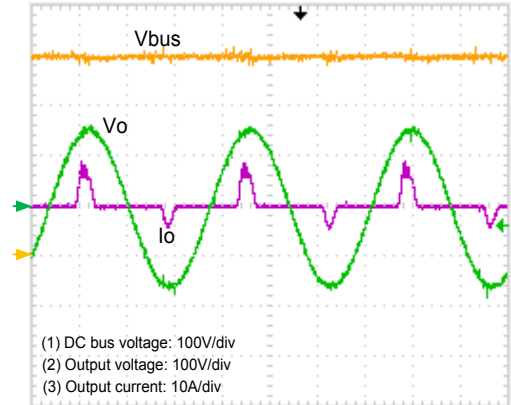

Fig. 21. DC bus, output voltage and current of the system for nonlinear load $-\mathrm{Vo}=110 \mathrm{~V}$. (100V/div.; 100V/div.; 10A/div.; 5ms /div.).

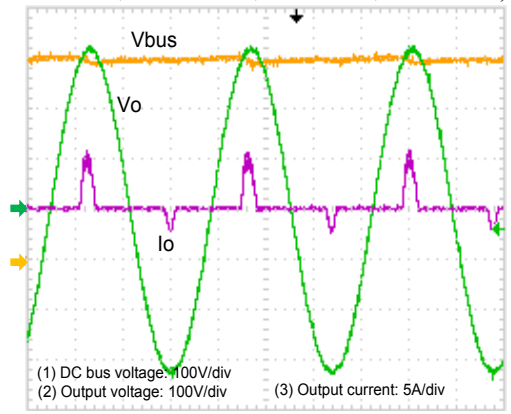

Fig. 24. DC bus, output voltage and current of the system for nonlinear load $-\mathrm{Vo}=230 \mathrm{~V}$. (100V/div.; 100V/div.; 5A/div.; 5ms/div.).

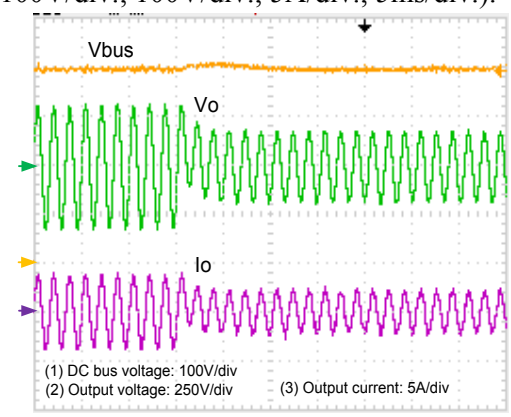

Fig. 27. DC bus, output voltage and current of the system for a voltage step. $(100 \mathrm{~V} / \mathrm{div}$.; 250V/div.; 5A/div.; 50ms/div.).

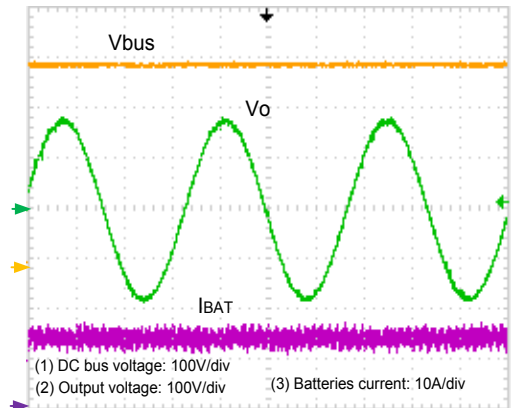

Fig. 22. DC bus, output voltage and current of the system for nonlinear load (100V/div.; 100V/div.; 10A/div.; 5ms/div.).

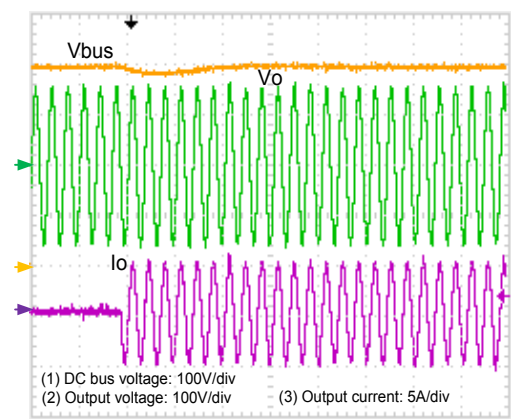

Fig. 25. DC bus, output voltage and current of the system for $\mathrm{Vo}_{0}=110 \mathrm{~V}$. $\quad(100 \mathrm{~V} / \mathrm{div}$; $100 \mathrm{~V} /$ div.; $5 \mathrm{~A} / \mathrm{div} . ; 50 \mathrm{~ms} / \mathrm{div}$.).

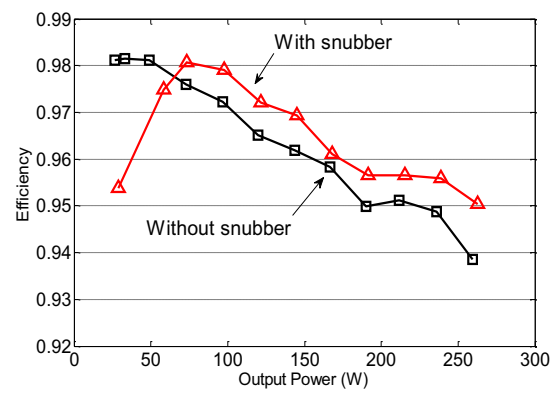

Fig. 28. Efficiency curves of the charge controller as function of output power. 
The rated power of charge controller is $300 \mathrm{~W}$, on the other hand this it is sufficient to provide the daily energy required in [2]. For output power greater than $70 \mathrm{~W}$, the converter presents higher efficiency when the snubber is applied. Thus, it demonstrated the snubber good performance for a wide range of load.

Figure 29 shows the efficiency curves of step-up DC-DC converter (second stage) and the inverter (third stage) for output voltage of $110 \mathrm{~V}$ and $230 \mathrm{~V}$. With output voltage equal to $230 \mathrm{~V}$, the inverter presents greater efficiency, reaching $95 \%$ at rated load. When the system operates with output voltage $110 \mathrm{~V}$, its efficiency reaches is only $90 \%$ for rated load. In the second case, the efficiency was lower than that in the first one, because the current is higher and consequently the semiconductor conduction losses also are.

The step-up DC-DC converter presents good efficiency, reaching $94 \%$ at nominal power.

The efficiency curves of the complete system as function of output power for both output voltages i.e. $110 \mathrm{~V}$ and $230 \mathrm{~V}$ are presented in Figure 30. With output voltage equal to $230 \mathrm{~V}$, the system presents greater efficiency, reaching $89 \%$ at rated load. When the system operates with output voltage $110 \mathrm{~V}$, its efficiency reaches is only $83 \%$ for rated load.

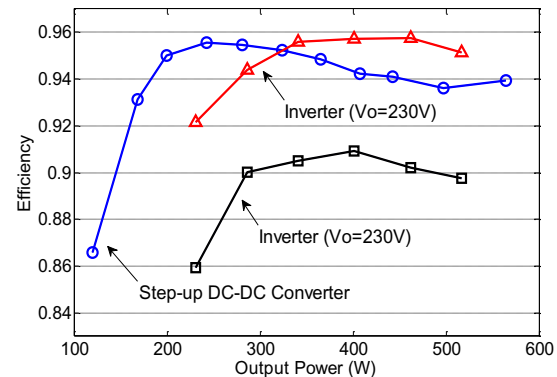

Fig. 29. Efficiency curves of the step-up DC-DC converter and inverter as function of output power.

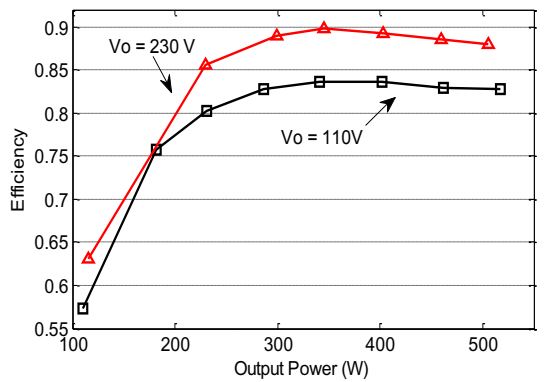

Fig. 30. Efficiency curves of the system as function of output power.

TABLE V

Total harmonic distortion of the output voltage system

\begin{tabular}{ccc}
\hline \multirow{2}{*}{ Output Voltage } & \multicolumn{2}{c}{ THD } \\
\cline { 2 - 3 } & Linear Load & NonLinear Load \\
\hline $110 \mathrm{~V}$ & $1.62 \%$ & $1.86 \%$ \\
\hline $115 \mathrm{~V}$ & $1.58 \%$ & $2.09 \%$ \\
\hline $120 \mathrm{~V}$ & $2.07 \%$ & $2.17 \%$ \\
\hline $127 \mathrm{~V}$ & $2.23 \%$ & $2.27 \%$ \\
\hline $220 \mathrm{~V}$ & $0.9 \%$ & $1.03 \%$ \\
\hline $230 \mathrm{~V}$ & $0.58 \%$ & $0.67 \%$ \\
\hline
\end{tabular}

Table V shows the total harmonic distortion (THD) of the system for every output voltage when the system supplies linear and nonlinear loads. Low THD for the output voltage is observed i.e. lower than $2.5 \%$, independently of connected load-type or rms value. It proves that the system is able to provide high quality sinusoidal voltage.

It is important to notice that the low de level in output voltage is introduced by the reference voltage of the inverter control system. In order to solve this problem, a capacitor can be used to block the de voltage.

\section{CONCLUSION}

This paper has proposed a stand-alone PV system with wide range for the output voltage, suitable for applications in isolated areas, where power grid can not reach.

Considering large scale production, this system is supposed to presents significant advantages, because it can implemented in several places also using the same hardware, thus reducing production costs. The output voltage can be set according to the particular specification of the installed area.

The system consists of three associated converters to process the energy generated by the PV panels. The theoretical analysis of each stage has been presented. A novel high voltage gain DC-DC converter based on SEPIC topology has also been proposed in this paper and used as the second stage of the system. The topology is suitable for this application, because this configuration protects the battery bank against any fault in the inverter.

Experimental results for a $500 \mathrm{~W}$ prototype have been presented to verify the performance of the proposed PV system. The results show that the PV panels operate at the maximum power point with high quality of the output voltage, while THD is lower than $2.5 \%$ over the whole operation range, independently of the nature of the connected load. Good performance has been achieved, with efficiency around $89 \%$, even though it can be improved by design optimization.

\section{REFERENCES}

[1] R.P.S. Leão, G.C. Barroso, R.F. Sampaio, J.B. Almada, C.F.P. Lima, M.C.O. Rego, F.L.M. Antunes, "The Future of Low Voltage Networks: Moving from Passive to Active", International Journal of Electrical Power \& Energy Systems, v. 33, p. 1506-1512, 2011.

[2] Ministério de Minas e Energia - MME 2033 "Programa Nacional de Universalização de acesso e uso de energia elétrica - Luz Para Todos (light for everyone)".

[3] "Coordinated control scheme for stand-alone PV system with nonlinear load", in Proc. of IEEE Transmission and Distribution Conference and Exposition, 2010 PES, vol., no., pp.1-8, 2010.

[4] X. Zhang, Z. Huang, Z. Liao, "Delay Synchronizing Rectification Control Strategy of Bi-Directional Converter in a Novel Stand-Alone PV System", in Proc.of PEITS '08., vol., no., pp.113-116, 2008

[5] J. Imhoff, J.R. Pinheiro, J.L. Russi, D. Brum, R. Gules, H.L. Hey, "DC-DC converters in a multi-string configuration for stand-alone photovoltaic systems", in Proc. of PESC 2008. vol., no., pp. 2806-2812, 2008.

[6] J. Imhoff, G.F.Rodrigues, J.R. Pinheiro, H.L. Hey, “A stand-alone photovoltaic system based on Dc-Dc 
converters in a multi string configuration", in Proc. of EPE' 07, vol., no., pp.1-10, 2007

[7] S. Daher, J. Schmid, F.L.M. Antunes, "Multilevel Inverter Topologies for Stand-Alone PV System", IEEE Transactions on Industrial Electronics, vol.55, no.7, pp.2703-2712, July 2008.

[8] S. Daher, J. Schmid, F.L.M. Antunes, "Current demand of high performance inverters for renewable energy systems", in Proc. EPE' 07, vol., no., pp.1-10, 2007.

[9] S.V. Araujo, R.P. Torrico-Bascope, F.L.M. Antunes, E. Mineiro Sa, "Stand-alone Photovoltaic System using an UPS Inverter and a Microcontrolled Battery Charger based on a Boost Converter with a 3 State-Commutation Cell”, in Proc of IECON' 06, vol., no., pp.4381-4386, 2006.

[10]"Projeto Microsolar - Conversor CC-CA Auto-comutado para Uso de Sistemas Fotovoltaicos Autônomos Utilizando No-break", Projeto Finep 01.04,0434.00, Universidade Federal do Ceará-UFC, Dpto. de Eng. Elétrica, Fortaleza-CE, Junho de 2009.

[11]G.V.T. Bascopé, I. Barbi, "Generation of a family of non-isolated DC-DC PWM converters using new threestate switching cells" in Proc. of PESC' 00. vol.2, no., pp. 858-863 vol.2, 2000.

[12]N. Femia, G. Petrone, G. Spagnuolo, M. Vitelli, "Optimization of perturb and observe maximum power point tracking method", IEEE Transactions on Power Electronics, vol.20, no.4, pp. 963- 973, July 2005.

[13]M.G. Molina, D.H. Pontoriero, P.E. Mercado, “An Efficient Maximum-Power-Point-Tracking Controller for Grid-Connected Controller Photovoltaic Energy Conversion System", Eletrônica de Potência SOBRAEP, vol. 12, no. 2, Jul 2007.

[14]C.M.T. Cruz, I. Barbi, "A passive lossless snubber for the high power factor unidirectional three-phase threelevel rectifier", in Proc of IECON'9, vol.2, no., pp.909914 vol.2, 1999.

[15]F.K.A. Lima, C.M.T. Cruz, F.L.M. Antunes, "Study of Passive Snubbers Applied to a Single-phase High Power Factor Rectifier" IEEE Latin America Transactions, (Revista IEEE America Latina), vol.2, no.2, pp.87-93, June 2004.

[16]W. Tang, F.C. Lee, R.B. Ridley, "Small-Signal Modeling of Average Current-Mode Control", IEEE Transactions on Power Electronics, vol.8, no.2, pp. 112119, April 1993.

[17]L.F. Costa; G.J.M. Sousa, R.P. Torrico-Bascopé, "Single-Phase PWM Inverter with Selectable Sinusoidal Output Voltage", in Proc. of CBA'10, 2010.

\section{BIOGRAPHIES}

Levy Ferreira Costa was born in Fortaleza, Ceará, Brazil, in 1986. He received the B.Sc. degree in Electrical Engineering from the Federal University of Ceará (UFC), Brazil, in 2010.

$\mathrm{He}$ is currently pursuing the MSc degree in electrical engineering at the Federal University of Santa Catarina, Florianópolis, Brazil. His main research interests include power supplies, power factor correction techniques, uninterruptible power systems, and renewable energy systems.

Eng. Costa is a student member of the Brazilian Power Electronics Society.

René P. Torrico-Bascopé received the B.Sc. degree in electrical engineering from San Simón University, Cochabamba, Bolivia, in 1992, and the M.Sc. and Dr. degrees in electrical engineering from the Federal University of Santa Catarina, Florianopolis, Brazil, in 1994 and 2000, respectively.

$\mathrm{He}$ is currently a Professor with the Department of Electrical Engineering, Federal University of Ceará, Fortaleza, Brazil. His main research interests include power supplies, power factor correction techniques, uninterruptible power systems, and renewable energy systems.

Dr. Torrico-Bascopé is a member of the Brazilian Power Electronics Society. 